\title{
Digital Platform Workers: Setting the HRM Research Agenda
}

\author{
Tay Lee Chin $^{1 *}$, Tan Fee Yean ${ }^{2}$ \\ ${ }^{1}$ Faculty of Accountancy, Finance and Business, Tunku Abdul Rahman University College, 53300 Kuala Lumpur \\ ${ }^{2}$ School of Business Management, Universiti Utara Malaysia, 06010 Sintok Kedah, Malaysia \\ *Corresponding author. Email: lctay@tarc.edu.my
}

\begin{abstract}
More full-time basis employees currently are looking into the gig workforce. While the digital platform workers are offered freedom in selecting jobs and flexible working hours, however, digital platform workers Malaysia could not be considered as employees who are entitled for employee benefits. Nevertheless, there is paucity of research concerning how Human Resource Management (HRM) theories and concepts apply in the gig workforce. This study aimed to examine to what extent HRM practices control gig workers. This paper proposed that digital platform workers are clearly different from the traditional employees. This paper explored how digital labor platforms control across the digital platforms among workers and customers. This paper also critically discussed how digital labor platforms influence the digital platform workers' autonomy and dependence. Implications for HRM research were also discussed. This paper improves our current understanding on the gig workforce and highlights the potential questions as future researches on HRM in the gig workforce.
\end{abstract}

Keywords: Digital labor platforms, digital platform workers, HRM theories

\section{INTRODUCTION}

The apps have changed the way Malaysians work and live [1]. For instance, a Malaysian uses apps to call the driver for the morning commute and recruit the web designer to develop the website. This results the existence of digital workforce, i.e., the labor market about short-term services for consumers and business clients [2]. The growth of digital workforce is driven by the rising cost of living as well as the job markets that become competitive. Many Malaysians especially fresh graduates, retirees, and students join the digital workforce [1]. The most visible digital platform workers can be seen driving ride-hailing services that includes Grab and Uber. Digital platform workers also can be found in white-collar professions such as healthcare and finance [1].

While the digital platform workers are offered freedom in selecting the job and flexible working hours, however, digital platform workers in Malaysia could not be considered as employees who are entitled for employee benefits such as career growth and minimum wages [3]. It is interesting to note that this phenomenon is different from the Human Resource Management (HRM) theories and researches who claim that employees can enhance organizations' performance and effectiveness [4][5]. The issue of how far HRM concepts apply to the digital workforce is lack of clarity. This restricts the understanding associated to gig workforce and the well-being of both organizations and workers. Hence, this study aimed to examine to what extent HRM practices control gig workforce. This paper contributes to the research by enhancing the understanding on how HRM practices are implemented in the gig workforce. It also serves as future research on HRM in the gig workforce.

\section{DEFINITIONS OF DIGITAL WORKFORCE}

[6] alleges that digital workforce is a workforce that uses the technology to fill the short-term service with workers who are independent contractors. In a similar vein, [7] refers digital workforce as an environment in which temporary positions is common, and organizations are using contract workers for temporary engagement.

\section{A FRAMEWORK FOR UNDERSTANDING DIGITAL LABOR PLATFORMS}

\subsection{To what extent does digital labor platforms recruit and select the workers?}

Unlike traditional organizations, digital labor platforms have no recruitment process on a timely basis. Digital platform workers are the ones who register on the digital labor platforms, and then they will be selected for the work assignment based on the digital labor platforms' algorithm. For instance, a ServiceHero i.e., Malaysian home-service 
app, customer enters the work request and then receives several qualified workers based on the suggestions of the algorithm. The final selection is in the hands of the customers.

\subsection{To what extent does digital labor platforms offer training and development for workers?}

Training and development opportunities are being offered to digital platform workers [8]. Not only that, online digital platforms also train and develop their partners [9]. It can be seen in the food delivery platforms such as Foopanda and Deliveroo, that request their partners, i.e restaurants, to make sure that the foods are ready on-time. This is to avoid the digital platform workers waiting at the restaurants.

\subsection{Do digital platforms workers have control over their compensation?}

The digital platforms workers have no autonomy to decide the compensation [9] The pay-rate in fact is determined by the digital labor platforms [10]. When the customers pay a fee to the digital labor platforms, the platforms take part of the fees while the remaining are transferred to the gig workers [11].

\subsection{Do digital platforms workers have control over their performance?}

In the digital labor platforms, customers' satisfaction determines the performance of the workers [9]. It is based on the star-rating system. For instance, each Grab driver has a driver rating which comprises of stars. In the case of Grab, if the Grab driver has a low driver-rating, they might unable to engage with Grab.

\section{RESEARCH IMPLICATIONS}

\subsection{Differentiation in construct-meaning application}

The biggest challenge in extending the HRM theory is to clarify the meaning and apply the constructs in the context of the digital economy. The meaning of the constructs can change based on the digital labor platforms or different types of digital platform workers. Some constructs may or may not be similar in the context for some digital platform works.

\subsubsection{Organizational support}

Based on the organizational support theory, employees develop a belief known as perceived organizational support about the extent to which employees value their contributions and concern their well-being [12][13]. Perceived organizational support leads to positive job attitudes and behaviors [13]. It results in both organizations' and employees' benefit: employees improve positive attitudes while organizations reap the benefits of perceived organizational support that may have useful consequences for the lower skill services provided by digital platform workers [6]. In such a situation, workers who are actively managed by digital labor platforms tend to view themselves as employees [6]. In contrast, perceived organizational support may not seem relevant to the higher skill services provided by digital platforms workers [6]. This is because digital platform workers with higher skills market their services on the digital labor platform with substantial autonomy that might not expect the organizations to care about their well-being [6].

\subsubsection{Organizational citizenship behavior}

Most of the digital platform workers spend their time to interact with customers [14]. This results in digital platforms workers who are more likely to engage in customer-directed Organizational Citizenship Behavior (OCB). Unlike traditional OCB that are much more focused on employees and organizations, customer-directed OCB focuses on customers [15]. Customer-directed OCB includes understanding the customers' needs, helping customers, and improving customer service [16]. Moreover, digital platform workers perceive the future work-request depending on the customers' ratings on the apps. It is likely that they will be more motivated going extra miles for the customers and engage in customer-directed OCB [14].

\subsubsection{Employee turnover}

Employee turnover is one of the human resource outcome variables that has not been linked to digital labor platforms [17]. Employee turnover is strongly associated with the digital workforce [6]. Ride-hailing platforms such as Uber and Lyft confront high driver-turnover [18][19]. Digital platform workers' intention to stay may be restricted, because these workers consider the work requests as their extra income [20]. Once they achieve their goals, they will simply leave the digital labor platforms [20].

\subsubsection{Job satisfaction}

It is necessary to consider the digital platform workers' job satisfaction on digital labor platforms. It is reported that most of these workers are satisfied with their jobs when they have greater autonomy in their work assignments and schedule [21]. Digital platform workers can also avoid bad managers and office politics [21]. Furthermore, past researches suggest digital platform workers who view digital labor platforms as primary income have higher job satisfaction [22][23].

\section{FUTURE RESEARCH DIRECTION}

Ride-hailing digital labor platforms compete with each other to recruit digital platform workers. Some ride-hailing 
platforms offer incentives and bonuses to digital platform workers. If the digital platform workers quit, digital labor platforms bear the recruitment, selection, and training costs. Hence, future studies are needed on how digital labor platforms manage and arrange to be attractive for those workers. Besides, how far digital platform workers' behavior can involve the digital labor platforms influences digital labor platforms' performance which is considered as an important question to explore in future researches. Digital platform workers have different motives to engage in the digital labor platforms and these motives influence how they view their works. Future researches should explore whether viewing works on the digital labor platforms can become the main source of income or whether a job can impact the engagement in digital labor platforms in the same ways.

\section{CONCLUSION}

More full-time basis employees currently are looking into the digital labor platforms. Digital labor platforms offer greater autonomy, flexibility, and opportunity to earn extra incomes. Digital labor platform claims using the HRM practices including performance management, training and development to manage the gig workers [24]. Therefore, this makes the digital platform workers' status increasingly controversial. It also raises the concern on how the digital labor platform manages the fairness and well-being of the gig workers. However, to date, most scholarly attentions focus on the needs of the customers rather than the wellbeing and welfare of the digital platform workers.

Digital platform workers are different from traditional employees. As discussed previously, there are huge differences in the work-related relationship between digital labor platforms and digital platform workers. Digital labor platforms play an important role in this relationship, because these platforms have the power to influence the interaction between digital platform workers and customers. Digital labor platforms also help to develop trust, which is crucial for digital platform workers and customers to engage each other. Besides, some digital labor platforms have the choice to reduce the digital platform workers' autonomy and dependence on the platforms. Such a working arrangement creates challenges for HRM research.

\section{ACKNOWLEDGMENT}

This research did not receive any specific grant from funding agencies in public, commercial, or not-for-profit sectors.

\section{REFERENCES}

[1] eRezeki, (2017). Now everyone can benefit from the digital economy. Retrieved from https://erezeki.my/en/home/

[2] Borneo Post Online. (2017). Hopping into the gig economy. Retrieved from http://www.theborneopost.com/2017/09/23/hoppinginto-the-gig-economy/

[3] Shanmugam, M. (2016). The gig economy only a stopgap measure to our woes. Retrieved from http://www.thestar.com.my/business/business news/2016/11/19/the-gig-economy-only-a-stopgapmeasure-to-our-woes/\#6SxlKyE5rPFQgoqD.99

[4] Edmans, A. (2012). The link between job satisfaction and firm value, with implications for corporate social responsibility. The Academy of Management Perspectives, 26(4), 1-19.

[5] Westgaard, R.H. \& Winkel, J. (2011). Occupational musculoskeletal and mental health: Significance of rationalization and opportunities to create sustainable production systems - a systematic review. Applied Ergonomics, 42(2), 261-296.

[6] Kuhn, K. M., \& Maleki, A. (2017). Microentrepreneurs, Dependent Contractors, and Instaserfs: Understanding Online Labor Platform Workforces. Academy Management Perspective, 31(3), 183-200.

[7] Throckmorton (2017), R. The 'Gig' Is Up! The Gig Workforce That Is. Retrieved from https://strategichrinc.com/article/the-gig-workforce/

[8] Mcquad, D. (2019). Training not being provided for contingent workers despite 1.5 million UK workers falling in to this category. Retrieved at https://www.hrreview.co.uk/hr-news/training-notbeing-provided-for-contingent-workers-despite-1-5million-uk-workers-falling-in-to-this-category/119733

[9] Meijerink, J., \& Keegan, A. (2019).

Conceptualizing human resource management in the gig economy: Toward a platform ecosystem perspective. Journal of Managerial Psychology, 34(4), 214-232.

[10] Lee, T. (2015). How much money is Grab making? Retrieved from https://www.techinasia.com/grabtaximake-money.

[11] Breidbach, C. F., \& Brodie, R. J. (2017). Engagement platforms in the sharing economy: 
conceptual foundations and research directions. Journal of Service Theory and Practice, 27(4), 761777.

[12] Eisenberger, R., Huntington, R., Hutchison, S., \& Sowa, D. (1986). Perceived Organizational Support. Journal of Applied Psychology, 71(3), 500-507.

[13] Rhoades, L., \& Eisenberger, R. (2002). Perceived organizational support: A review of the literature. Journal of Applied Psychology, 87(4), 698714.

[14] Harvey, J., Bolino, M. C., Kelemen, T. K. (2018). Organizational citizenship behavior in the 21st Century: How might going the extra mile look different at the start of the new millennium? Research in Personnel and Human Resources Management, 36, 51-110.

[15] Brown, T. J., Mowen, J. C., Donavan, T. D., \& Licata, J. W. (2002). The customer orientation of service workers: Personality trait determinants and effects on self- and supervisor performance ratings. Journal of Marketing Research, 39(1), 110-119.

[16] Saxe, R., \& Weitz, B. A. (1982). The SOCO scale: A measure of the customer orientation of salespeople. Journal of Marketing Research, 19(3), 343-351.

[17] Cappelli, P., \& Keller, J. R. (2013). Classifying work in the new economy, Academy of Management Review, 38(4), 575-596.

[18] Brown, E. (2019). Uber and Lyft face hurdle of finding and keeping drivers. Retrieved from https://www.wsj.com/articles/uber-and-lyft-face tough-test-of-finding-and-keeping-drivers11557673863

[19] Pymnts, (2019). Uber, Lyft struggle to keep drivers on board. Retrieved from https://www.pymnts.com/news/ridesharing/2019/uberlyft-drivers/

[20] Sullivan, J. (2019). What's wrong with hiring a gig workforce? Pretty much everything. Available at https://drjohnsullivan.com/articles/whats-wrong-withhiring-a-gig-workforce-pretty-much-everything.

[21] Milligan, S. (2019). Gig workers challenge old order. Retrieved from https://www.shrm.org/hrtoday/news/all-things-work/pages/gig-workerschallenge-old-order.aspx
[22] Spreitzer, G.M., Cameron, L. and Garrett, L. (2017). Alternative work arrangements: two images of the new world of work. Annual Review of Organizational Psychology and Organizational Behavior, 4(1), 473-499.

[23] Keith, M. G., Harms, P., \& Tay, L. (2019). Mechanical Turk and the gig economy: Exploring differences between gig workers. Journal of Managerial Psychology, 34(4), 286-306.

[24] Duggan, J., Sherman, U., \& Carbery, R. Mcdonell, A. 2019. Algorithmic management and appwork in the gig economy: A research agenda for employment relations and HRM. Human Resource Management Journal, 30(1), 114-132. 